\title{
Firearm Violence and Effects on Concealed Gun Carrying: Large Debate and Small Effects
}

\author{
Jeremy G. Carter, Ph.D. ${ }^{1}$ \\ School of Public and Environmental Affairs \\ Indiana University - Purdue University Indianapolis \\ 801 W. Michigan Street / BS 4081 \\ Indianapolis, IN 46202 \\ carterjg@iupui.edu \\ Michael Binder, Ph.D. \\ Department of Political Science and Public Administration \\ University of North Florida \\ 1 UNF Drive \\ Jacksonville, FL 32224 \\ m.binder@unf.edu
}

\begin{abstract}
Research has yet to identify a predictive relationship between crime and the issuance of aggregated concealed gun permits. The present study examines if a macro-level relationship exists between both concealed carry firearm applications and permits and violent crime committed with a firearm. Florida county-level data for concealed carry applications and violent crime are combined with police employment, socioeconomic, political, and firearm subculture variables across two temporal periods using both county and year fixed effects models. Unstandardized negative binomial regressions are employed with multiple alternative model specifications and diagnostic tests. Findings indicate a positive association between crime, especially those committed with a firearm, and concealed carry applications and permits. The effect size of firearm violent crime on concealed carry applications and permits is minimal. There is a demonstrable link between firearm violence and concealed carry applications and permits issued, net all covariates. Findings should be tempered by the minimal effect sizes.
\end{abstract}

\section{Keywords}

Concealed carry, firearm violence, self-protective, time series, fixed effects

\section{Citation}

Carter, J. G. \& Binder, M. (2016). Firearm violence and effects on concealed gun carrying: Large debate and small effects. Journal of Interpersonal Violence. DOI: 10.1177/0886260516633608.

\section{Link}

http://jiv.sagepub.com/content/early/2016/02/24/0886260516633608.abstract

${ }^{1}$ Corresponding author 


\section{Firearm Violence and Effects on Concealed Gun Carrying: Large Debate and Small Effects}

\section{Introduction}

The intersection of violent crime and gun carrying has been a focal point of considerable research and public debate. In the area of legal gun carrying, research has primarily focused on the relationship between states allowing citizens to carry concealed guns and an associated impact on crime (Ayers \& Donohue, 1999; Black \& Nagin, 1998; Kovandzic \& Marvell, 2003; Lott, 2000; Lott \& Mustard, 1997; Plassman \& Tideman, 2001). A more limited body of work has pursued explanations of legal gun carrying; specifically concealed firearm carry permits. To date, four studies have explored indicators of aggregate-level concealed carry permits (Costanza \& Kilburn, 2004; Costanza, Kilburn, \& Miles, 2013; Gau, 2008; Thompson \& Stidham, 2010); none of which have found a systematic relationship between crime and the issuance of permits to carry a concealed firearm.

This relationship merits further examination for two primary reasons. First, evidence suggests that violent crime is a predictor of legal gun ownership (Bordua \& Lizotte, 1979; Kleck \& Kovandzic, 2009) and legal handgun purchases (McDowall \& Loftin, 1983). Moreover, fear of victimization has been linked to legal gun ownership within an individual's home (Miethe, 1995; Warr \& Ellison, 2000) as well as carrying an illegal gun in public for purposes of self-protection (Bankston \& Thompson, 1989; Vacha \& McLaughlin, 2000; Watkins et al., 2008). Thus, it seems reasonable to assume violent crime could predict legal concealed firearm carrying. Second, a methodological hindrance to gun carrying and violence research is simultaneity (Marvell \& Moody, 1996), wherein statistical models struggle to identify the direction of the causal relationship between crime and gun carrying. Research has predominantly focused on the effect of 
concealed carry laws on violence, not vice versa. Thus, only one side of the simultaneity equation has received the bulk of scholarly attention. To progress the discussion of violence as a predictor of legal gun carrying, the present research examines the linkage between violent crime and concealed carry gun permit applications and permits while employing methods to detect and correct for issues of simultaneity.

There are salient implications for exploring if individuals react to violent crime by seeking to legally carry guns. As the proportion of crimes committed with a firearm increase, so too does the likelihood that such crimes will result in fatal injuries (Cook, 1991). The extent to which criminals perceive increases in civilian gun carrying is uncertain. However, it is likely that criminals develop their perceptions of the prevalence of civilian gun carrying in response to the publicity surrounding concealed carry laws and incidents - what Zimring and Hawkins (1997) term an “announcement effect.” Given the media attention Florida receives related to legal gun carrying incidents as well as the sheer number of legal gun carriers; a total of 1,654,052 valid conceal and carry permits as of November 30, 2015 (Florida Department of Agriculture and Consumer Services, 2015), this announcement effect is worth consideration by policy makers and scholars alike.

\section{Aggregated Data and Individual Rational Choice}

The present research focuses on the influence of community violent crime rates on aggregate-level indicators of concealed carry permits applied for and issued to determine whether legal gun acquisition is influenced by patterns of local violence. This inquiry is predominantly driven by two areas of the literature; 1) individuals may react to factors associated with security 
and crime that influence the decision to rely upon guns for self-protection, and 2) aggregate data provide an avenue to discover patterns of individual rational choice.

To begin, scholars positing the collective security hypothesis contend that fear of crime, coupled with the perception of inadequate police response to protect citizens, influences individual decisions to rely upon a gun for self-protection (Carlson, 2012; Gau, 2008; McDowall \& Loftin, 1983; Smith \& Uchida, 1988; Young et al., 1987). Black’s (1980) articulation of the "self-help" hypothesis mirrors this argument. Scholars have tried to parse out the complexity of the collective security hypothesis through an understanding of legal guns as a response to crime (Garland, 2002; Simon, 2002; 2004; 2007). Individual decisions to seek out guns as a self-protective measure are influenced by the development of perceived risk of victimization.

Interactions among neighbors, friends, and family are believed to serve as exposure mechanisms that inform people of local victimization (Drakulich, 2015). In the same manner that these social interactions generate community cohesion, these same processes provide forums where crime and victimization can diffuse among community members (Bellair, 1997; Sampson et al., 1997). An awareness of criminal activity within geographic areas can cause indirect victimization that has been found to increase fear (Tyler, 1980). Moreover, perceptions of increased risk severity heightens sensitivity to possible victimization and subsequent protective measures (Box, Hale \& Andrews, 1988; Warr, 1987; Wilcox-Rountree, 1998). Scholars have concluded that interpersonal violence, especially the most serious forms of violence, are more likely to diffuse among social groups (Browning, Dietz \& Feinberg, 2004; Cohen \& Tita, 1999; Kleck \& Kovandzic, 2009; Mears \& Bhati, 2006; Morenoff, Sampson \& Raudenbush, 2001; Smith, Frazee, \& Davison, 2000). 
Given rates of violent victimization vary greatly across geographic area that are racially heterogenic, economically disadvantaged, and socially disorganized versus those that are not (Lauritsen \& Carbone-Lopez, 2011), aggregated data of larger geographic areas can assist in the discovery of trends at the individual-level. The use of such aggregate data for individual choice is viewed as an appropriate empirical method to develop underlying behavioral models (Hartman, 1982). This approach is more commonly employed in economics research to identify patterns of rational individual-level behavior in response to macro-level events (Becker, 1976). This method has been employed by criminologists to explore individual decision making. For example, Levitt (1998) leveraged this theoretical approach in his examination of the sharp disparity between adult and juvenile sentencing from 1978-1993. He notes that “...the divergence of juvenile and adult crime rates may not be the result of teenagers who differ categorically from earlier generations, but rather a [individual] rational response to a change in the relative incentives for juveniles and adults to engage in criminal activities” (p.1157). The present research hypothesizes that as violent crime - especially crime committed with a firearm - increases within a county, individuals may make the rational decision to seek a concealed carry firearm permit for self-protection. As individual-level data is not readily available to explore this potential response, county-level data are employed in an attempt to discover if such a relationship may exist. As will be discussed, the present study examines this potential criminal response through causality tests for simultaneity.

\section{Aggregate Legal Gun Carrying}

The following review of relevant literature centers specifically on studies seeking to explain aggregate-levels of legal concealed gun carrying. There are four studies in this specific area of inquiry. First, Gau (2008) employed 1999 neighborhood-level data in the city of Spokane, 
WA to explore the effects of social cohesion, police service levels, and of crime as predictors of concealed carry permits within neighborhoods. Drawing on neighborhood surveys and administrative data using a weighted structural equation path model, Gau (2008) concluded that the level of police service had a negative indirect effect on neighborhood concealed carry permits through fear of crime. She also concluded that violent crime had no effect on permits, but fear of crime was a strong positive predictor of concealed carry permits. Gau (2008) argued that people may seek concealed carry permits as a method of self- and social-protection given positive effects of social cohesion and fear of crime, as well as, low levels of police service within neighborhoods.

Second, Costanza and Kilburn (2004) examined rates of concealed carry permits in Louisiana. Using data from 1998, they found that rates of concealed carry permits issued in Louisiana were positively associated with median home income, political conservatism, white population, and less populated areas. When coupled with no observed effect from crime on the rate of permits issued, these findings led the authors to conclude the decision to seek a concealed carry permit was likely more symbolic of being a wealthy, politically conservative white person as opposed to someone in fear of crime (Costanza \& Kilburn, 2004). Third, Thompson and Stidham (2010) built upon the Louisiana study by disaggregating race and including hunting permit rates under the belief that a sporting subculture would be predictive of concealed carry permit rates. Employing data from North Carolina counties in 2005, and controlling for similar socioeconomic and political variables as Costanza and Kilburn (2004), Thompson and Stidham (2010) concluded that income and crime had no significant effect on permits issued. However, the authors found evidence that a sporting subculture and political conservatism were positively associated with concealed carry permit rates. 
Lastly, Costanza, Kilburn and Miles (2013) replicated the work of Thompson and Stidham (2010) using data from select towns in Connecticut in the year 2000. The authors concluded, again, that crime has no relationship with the rate of concealed carry permits issued. Support was also found for political conservatism's impact on concealed carry permits, while median household income was observed to have a negative effect. Moreover, using geographic data to account for spatial proximity and population density, the authors found that crime was highly correlated with population density in their data, and that the latter was negatively associated with concealed carry permit rates. Such a finding may lend support to the notion that a symmetrical relationship exists between crime and concealed carry permits; however such a finding was not observed in the Connecticut data and future research in this area was encouraged. Replicating control measures and employing data across two longer periods of time in the state of Florida, the present study seeks to further this body of knowledge by establishing a county-level relationship between violent crime and concealed carry permits applied for and issued.

\section{Methodology}

The National Research Council (2004) noted that evidence from studies of concealed firearm carrying were sensitive to minor changes in model specification. This, coupled with the lack of supporting evidence to date associated with violent crime as a predictor of concealed carrying, has driven the present research to employ multiple model specifications using two different time periods. The current study utilizes county-level panel data from all 67 counties in Florida. Due to limited availability of a key control variable, models utilize two temporal periods of 2005-2012 and 1996-2012. Data for one of the key control variables, hunting licenses, was not available until 2005. The current study utilizes a dosage effect of both the number of concealed 
carry permits applied for and issued in each county. Research to date has yet to employ applications as a variable of interest.

The decision to include applications for concealed carry permits is believed to be more reflective of persons seeking self-protective behaviors. Totals provided by the Florida Division of Licensing indicate that from 1987-2013 (Florida's shall-issue law went into effect in 1987) there is just over a two percent difference between applications received and permits issued. This difference may seem negligible, however statewide totals do not account for variation of applications received and permits issued by county across time. County-level differences, such as incidents of violent crime, can vary and thus influence perceptions of the need to carry a firearm. Despite not being issued a permit, this two percent difference is representative of peoples' desire to carry a concealed firearm and thus merits inclusion. The driving research question for the present study is rather straightforward; do increases in violent crime rates within a county prompt citizens to apply for concealed carry permits? It is anticipated that violent crime committed with a firearm will have a different, and positive, effect on concealed carry permits applied for and issued in comparison to violent crime committed without a firearm.

\section{Data}

In order to test these questions we use county level data from each of the 67 counties in the state of Florida. Florida's Department of Agriculture and Consumer Services' Division of Licensing electronically provided county level data on the number of civilian concealed carry weapons permit applications and permits issued. ${ }^{2}$ Violent crime is measured using UCR index

\footnotetext{
${ }^{2}$ CCW permits are applied for and issued at the state level. However, the county level data used in this research reflects where the applicant/permit holder permanently resides within the state of Florida. By Florida law, this is the most granular level at which CCW applicant/permit holder data is made available.
} 
offenses of violent crime (homicide, rape, robbery, aggravated assault) and was provided electronically by the Florida Department of Law Enforcement. To best isolate violent crime in the present study, index crimes are parsed out by those committed with and without a firearm as crime committed with a firearm may invoke more self-protective behavior (Cao, Cullen, \& Link, 1997).

The present study includes seven specific control variables that theory and prior research suggest are corollary antecedents to both crime rates and concealed carry applications and permits. Concealed carry permit holders predominantly reside in areas with higher per-capita incomes (Costanza \& Kilburn, 2004; Hood \& Neeley, 2000). Thus, if counties with lower per-capita incomes generally have higher levels of violent crime (Morenoff \& Sampson, 1997), but lower permit rates, then failing to control for the economic well-being of counties might lead to a spurious negative relationship between permit rate and crime (Kovandzic \& Marvell, 2003). In order to control for these potential confounds, we include the economic variables of unemployment and per capita income. County level unemployment was gleaned from the United States Department of Labor’s Bureau of Labor Statistics’ Local Area Unemployment Statistics program. County-level per capita income data was taken from the United States Department of Commerce's Bureau of Economic Analysis.

Population density has been linked to protective gun ownership (Giblin et al., 2011) and concealed carry permits in rural areas (Costanza, Kilburn, \& Miles, 2013; Thompson \& Stidham, 2010). In order to control for this potential relationship we include a measure of population density (population per square mile) using data obtained electronically from the Florida Office of Economic and Demographic Research. Because racial demographics have been linked to gun ownership (Dixon \& Lizotte, 1987) and concealed carry permits (Costanza \& Kilburn, 2004; Thompson \& Stidham, 2010), we include the percentage of county population that is white (non- 
Hispanic) as determined from the most recent United States Census Report. Partisan composition of counties (measured by the percentage of registered Republicans) is included as it has been associated with legal gun carrying (Costanza, Kilburn, \& Miles, 2013; Costanza \& Kilburn, 2004; Donohue \& Ayers, 1999; Grossman \& Lee, 2008; Thompson \& Stidham, 2010). Party registration data was obtained electronically from the Florida Department of State's Divisions of Elections.

Gau (2008) concluded that police service levels had a direct negative effect on concealed carry permits, as well as, a suppressive effect on fear of crime within neighborhoods. As such, the present study includes the total number of sworn officers from county, municipal, and university agencies within each county as taken from the Federal Bureau of Investigation's Uniform Crime Report Police Employee Data for each given year within our varying model specifications. Lastly, gun ownership and gun carrying have been linked to southern and sporting subcultures (Bankston et al., 1990; Lizotte, Bordua \& White, 1981; Thompson \& Stidham, 2010). Though the effect of such subcultures on individual gun behaviors is debatable, especially with respect to legal gun carrying for protection (Felson \& Pare, 2010), it remains prudent to control for in the present study. Since our research design uses county fixed effects within a southern state (Florida), the southern subculture thesis is controlled for with our modeling choice. We include the total number of hunting licenses sold within each county for each year as a measure of sporting subculture. Hunting license data was obtained electronically from the Florida Fish and Wildlife Conservation Commission and was only available beginning in 2005.

\section{Analytic Strategy}

Analysis of UCR crime rates, especially at the county-level, has been a source of debate in the literature (Maltz \& Targonski; 2002; Osgood, 2000; Pridemore, 2005). The present study 
employs fixed-effects negative binomial regressions to regress the number of concealed carry applications and permits on violent crime and a series of control variables. Using a negative binomial regression model to analyze over-dispersed count data (such as concealed carry applications and permits noted in Table 1) is more efficient than Ordinary Least Squares (Cameron and Trivedi, 2013) and is a more flexible modeling technique with less restrictive assumptions than traditional Poisson models (Gardner, Mulvey \& Shaw, 1995). Counties vary in size and therefore counts are not necessarily comparable across counties. Count models account for these differences by including the log of the exposure variable (county population) in the model with its coefficient constrained to one. Models are estimated in Stata using the "xt" commands (Cameron \& Trivedi, 2013). Two-tailed tests are conducted to ensure proper interpretation of results.

While some generalizability is lost from limiting the analysis to a single state, the benefit of improved estimation and controlling for statewide idiosyncrasies outweighs that cost. The overestimation of significance levels in county-level studies because of the "clustering" of error terms at the state level is a serious concern. Moody (2001) contends that scholars examining rightto-carry laws and crime using county-level data have overestimated the statistical significance of their findings because of correlation of variables within states. In such a situation, standard errors can be substantially biased downward, leading to inflated t-ratios for the shall-issue law variable. Using Lott and Mustard's (1997) county-level data and robust Huber-White standard errors, which do not require independence of observations within clusters (e.g., shall-issue states), Moody (2001) found that the robust standard errors for the shall-issue law dummy variables in the homicide regressions were much larger than the conventional standard errors.

Most research on legal gun carrying has utilized county-level UCR data that have been argued to be highly suspect due to inconsistent (or missing) reporting and attempts to impute 
missing data are incomplete and change across time (Maltz \& Targonski, 2002). While countylevel data are not without obstacles, Lott and Whitley (2003) note that no data are perfect and that county data do not face as great an aggregation problem as state data and do not miss the large portions of the state lost by city level data. Specific to this issue in the same state as the present research, in their study of Florida’s shall-issue law, Kovandzic and Marvell (2003) removed ten counties from their analysis because they believed errors existed with respect to crime reporting. These counties are each not very populous and thus do not report many crimes. For purposes of the present study, in-depth discussions were conducted with crime analysts and statistical personnel from the Florida Department of Law Enforcement regarding these reporting issues. Following these discussions, we concluded that the inclusion of all 67 counties was pertinent for the present study. However, in an effort to account for the possibility that there are missing or misreported data in these few counties, we provide two models for each model specification. One model with all 67 counties and an additional model with limited counties wherein the 12 potentially under-reported counties ${ }^{3}$ were removed from the analyses.

Each model utilizes both county and year fixed effects that account for time invariant cross county differences (local ordinances) and unobserved influences that affect each county equally in a given year (national economic conditions, state laws or federal laws). The models measure the year-to-year deviations in concealed carry applications and permits for that county as a function of the treatment variables in each time period. The models measure the average treatment effect of the violent crime rate on the number of concealed carry applications and permits in each county, and the coefficients produced for the 67 county regression models represent an average of the

\footnotetext{
${ }^{3}$ These counties were: Calhoun, Franklin, Gilchrist, Glades, Gulf, Hamilton, Holmes, Jefferson, Lafayette, Liberty, Okeechobee and Suwannee.
} 
treated counties’ effects. Thus, the coefficients for the key independent variables in Tables 2-7 (violent crime committed with and without a firearm) reflect an average of within-county averages. Effects are estimated based on variation within counties, not a pooled cross-sectional estimate of the effects.

When combining data from multiple state and federal agencies, measurement is not always consistent. For example, UCR and census data are based on the calendar year; however, data from the state of Florida are based on the Florida fiscal year; July 1 through June 30. Therefore, in order to properly account for the theoretical expectation that increases in armed violent crime precedes increases in concealed carry permitting, lagged measures of federal data (violent crime, unemployment, income, race, partisanship, and population density) are employed. The lagged federal and partisan data has a six-month overlap (July of year X-1 through December of year X1) with data kept by the state of Florida (concealed carry applications and permits, hunting licenses, and sworn officers). This helps to ensure a proper temporal ordering of the independent and dependent variables.

The issue of simultaneity, the potential of an endogenous regressor variable being correlated with the error term, has been discussed and accounted for in previous gun and violent crime studies (see Kovandzic \& Marvell, 2003; Marvell \& Moody, 1996; Stolzenberg \& D’Alessio, 2000). In an effort to test for simultaneity, a Granger causality test was conducted using two separate models. The first model uses the key independent variable (violent crime committed with a firearm) as the dependent variable, with one year lagged values of armed violent crimes and concealed carry applications. Results of this diagnostic model indicate violent firearm crime in the previous year predicts violent crime in the current year. Concealed carry applications in the previous year however, have no effect on armed violent crime. These results lend confidence to 
the notion that criminals are not making the rational decision to use more violent force to commit crime.

The second model reverses the measures and employs applications as the dependent variable and firearm crime as the independent. Both of these diagnostic models were conducted for concealed carry applications as well as permits. Results indicate firearm violence is a positive and statistically significant predictor of concealed carry applications and permits. Although Marvell and Moody (1996) assert the Granger Test of causality is the most appropriate diagnostic of simultaneity, a Hausman specification error test was also employed as a supplemental analysis to determine whether simultaneity is a threat to the models presented (see Hausman, 1978). The Hausman test results confirmed those of the Granger test. ${ }^{4}$ These results lend confidence that concealed carry applications and violent crime committed with a firearm are mutually exclusive and that models presented are free of simultaneity.

\section{Results $^{5}$}

Table 1 provides the descriptive statistics for measures included in the present study within both the 2005-2012 and 1997-2012 time periods. Three generalities emerge from the descriptives

\footnotetext{
${ }^{4}$ Coefficients and standard errors of these diagnostic models are not presented given space considerations, but can be provided by the authors upon request.

${ }^{5}$ Given substantial academic debate regarding model specification and concealed carry research, linear regression models were employed for robustness and confirmatory purposes. Linear regression estimation used Driscoll-Kraay standard errors to account for both autocorrelation and cross-sectional dependence, thereby allaying concerns about “clustering” (Driscoll \& Kraay, 1998). Results pertaining to these confirmatory models are not reported for space considerations, but can be provide by the authors upon request. Linear regression models confirmed findings of the negative binomial models. Crimes committed with a firearm had a significant positive effect on both concealed carry applications and permits across each model tested. Control variable effects were sporadic across the confirmatory models; however, there did appear to be a trend of support for positive socioeconomic (unemployment and income) and negative population density effects. A higher proportion of whites in a county was only a significant predictor in the 1996-2012 permit models. A sporting culture (hunting licenses) was only a significant predictor of permits, not applications. Police service levels have a positive effect on concealed carry applications and permits across each model tested. Additional models were specified with all violent crime included. These additional models confirmed the findings of the models presented. The coefficient for the "all violent crime" variable in the $2005-2012$ model was .00016 and for the 1997 - 2012 model the coefficient was .0000178. Full model reports can be provided upon request.
} 
presented in Table 1 and are consistent across both time periods. First, the concealed carry permit applications and crime rates data vary dramatically between counties and years. The minimums and maximums for each variable have very large ranges, partially due to the variance in county populations, and partially do the length of the time series. Second, there are three counties in four years that did not encounter any violent crime committed with a firearm. Each county is sparsely populated and sees very little violent crime, and even less violent crime with firearms. Additionally, the authors discussed the "0" values with FDLE crime statistics personnel and were repeatedly told those particular values were actually reported as " 0 " and not "missing." The county data for all of the crime rates are censored at zero and also heavily right skewed. The control variables have much less variability (except county population size), as the standard deviations are less than half of the value of the mean. Lastly, consistent with national trends, the average frequency of concealed carry applications and permits is notably higher during the shorter and more recent 2005-2012 time period.

\section{[ Table 1. Florida County Level Descriptive Statistics for Dependent and Independent Variables for 2005-2012 and 1997-2012 approximately here ]}

Evidence presented in Table 2 suggests a relatively clear pattern of the effect of firearm crime on county-level applications for concealed carry permits. Across the two different time periods, and models that include both all counties and limited counties, firearm crime has a positive and statistically significant effect on concealed carry applications. Interestingly, significant negative effects are observed between non-firearm crime and concealed carry applications during the 1997-2012 period. This finding is consistent with the assumption that firearm violence has a 
greater influence on applications for concealed carry permits as compared to non-firearm crime. ${ }^{6}$ Table 2 presents evidence in support of higher socio-economic conditions, lower population density, race, and a sporting culture as predictors of concealed carrying. It is important to note the consistent, and relatively minimal, coefficients and standards errors across the models. Though statistically significant, the effects lack substantial influence on the increase of applications.

\section{[ Table 2. Unstandardized Negative Binomial Regression Coefficients from Multiple Regression of Concealed Carry Applications on Violent Crime and Control Variables with County and Year Fixed Effects approximately here ]}

Table 3 presents results of the primary model specifications and concealed carry permits as the variable of interest. As expected, results pertaining to firearm crime almost mirror those within the aforementioned models exploring concealed carry applications. Crimes committed with a firearm have a significant positive effect on concealed carry permits. A negative relationship is again observed between non-firearm crimes and permits in the 1997-2012 period. Unemployment, race, and population density control variables are again significant. There are, however, notable differences from the applications model with respect to the control variables. Hunting licenses do not influence permits while police service levels have a positive effect on permits from 1997-2012. The latter finding is somewhat perplexing, as the direction of this relationship would seem to be reversed. This finding will be explained further in the discussion section to follow. Lastly, the observed effect sizes are further reduced from the already minimal effects noted in the application models.

\footnotetext{
${ }^{6}$ As a robustness check we provided two bivariate correlation matrices in the Appendix. The first correlation matrix includes data from 2005 - 2012 and the second includes data from 1997 - 2012. None of the independent variable bivariate correlations are higher than .70, a key threshold for inclusion in a multivariate regression (see Tabachnick and Fidell 2001).
} 


\section{[ Table 3. Unstandardized Negative Binomial Regression Coefficients from Multiple Regression of Concealed Carry Permits on Violent Crime and Control Variables with County and Year Fixed Effects approximately here ]}

Firearm Violence by Crime Type

To further explore firearm violence and concealed carry permits, negative binomial models estimating the effects by crime type (homicide, rape, robbery, and aggravated assault) committed with a firearm are provided. Table 4 presents results of concealed carry applications across both time periods. Table 5 presents results of concealed carry permits across both time periods. Robbery and aggravated assault committed with a firearm are significant positive indicators across every model. Homicide with a firearm is a predictor in three of the four models (not in 2005-2012 applications). Interestingly, when permits are the dependent variable (Table 5), each of the four crimes is significantly positive during both time periods. Moreover, crime severity appears to influence effect size. Coefficients for homicide and rape are higher than robbery and aggravated assault. Though these effect sizes are slight at best, they further support the theoretical position that levels of violence may influence concealed weapons carrying.

[ Table 4. Unstandardized Negative Binomial Regression Coefficients from Multiple Regression of Concealed Carry Applications on Violent Crime Types and Control Variables with County and Year Fixed Effects approximately here ]

[ Table 5. Unstandardized Negative Binomial Regression Coefficients from Multiple Regression of Concealed Carry Permits on Violent Crime Types and Control Variables with County and Year Fixed Effects approximately here ] 


\section{Conclusion and Discussion}

The findings in this research indicate that as counties in the state of Florida experience greater numbers of firearm violence, the citizens of those counties may react by applying for permits to carry a concealed firearm, net of relevant covariates. From a theoretical perspective, the finding of firearm crime as a predictor of concealed carrying is the first such demonstrable relationship and provides evidence that should solicit further investigation. The present study provides evidence in support of higher socio-economic status (Costanza \& Kilburn, 2004), lower population density (Costanza, Kilburn \& Miles 2013), higher proportion of whites (Costanza \& Kilburn, 2004; Thompson \& Stidham, 2010), and a sporting culture (Costanza, Kilburn \& Miles 2013) as predictors of concealed carrying. Moreover, these models suggest that per capita income may be a more reliable socioeconomic measure across time. Though not directly measured in the present study, the findings suggest fear of crime may be correlated with an individual's desire to pursue a concealed carry license.

A theoretically perplexing finding was that police service levels were shown to have a positive effect on concealed carry applications and permits. This relationship is in the opposite direction as expected, as increases in police service levels are believed to have a suppressive effect on concealed carrying. One plausible explanation for this finding may be that increases in violent crime were met with increases in police personnel, yet diagnostic tests revealed no correlation between firearm crime in year one and police service levels in year two. It is also unlikely that additional police would be hired in response to firearm crime as public safety budgets in Florida were rather sparse and the temporal time frame is short for hiring purposes. Though it cannot be said for certain, this relationship may be spurious within the available data. Nonetheless, it appears 
prudent to include police service levels in future examinations of predictors of concealed carrying. Future studies should also attempt to capture individual-level perceptions and behaviors, as well as, meso-/macro-level data similar to Gau's (2008) study. Relatedly, counties are typically large geographies that may consist of varying high- and low-crime areas within a single county. As the growing literature regarding crime and place has shown, micro-units of place are more ideal than larger areas defined by formal boundaries (i.e., county lines). Future research examining concealed gun carrying and crime should attempt to gather micro-meso levels of data to better isolate environmental differences within counties, or perhaps on the boundaries between counties.

Deterrence and rational choice theory posits that an increase in the perceived costs of crime - the likelihood of encountering an armed victim - may deter criminal activity, particularly as the number of permits issued within a state increases over time (Lott \& Mustard, 1997). The opposite effect is a policy issue that is commonly overlooked; the potentially undesirable and adverse changes in the behavior of criminals in response to perceptions of increased civilian gun carrying (Ludwig, 2000). For example, recent research suggests robbery offenders make determinations on the amount of force to use at the onset of a robbery based on their perception of a potential victim's likelihood that they are carrying a weapon (Lindegaard, Bernasco, \& Jacques, 2014). Wright and Rossi (1994) interviewed imprisoned offenders who used firearms to commit their crimes and noted that approximately two-thirds reported that the decision to carry a gun for purposes of committing their crime was influenced by the prospect of encountering an armed victim. It is plausible that such perceptions among criminals may lead to increases in the use of firearms to commit violent crime where previously such levels of force were not utilized. Respondents to the 2012 National Crime Victimization Survey indicated that only seven percent of violent crime was 
committed with a firearm, a proportion that has been consistent since 2003 (Truman, Langton \& Plenty, 2013).

Though the association found between armed violent crime rates and concealed carry permit application rates was consistent, it was also minimal in magnitude. It seems the level of debate surrounding violence and concealed carrying far outweighs any observed effects. While it appears armed violent crime is related to higher levels of concealed carry applications and permits, we acknowledge that other factors are just as - if not more - important and highlight the need for more refined research to parse out any plausible relationships. Moreover, it should be noted that the relationship between other explanatory variables (such as population density and unemployment) and concealed carry permit application rates was substantively larger than was found for armed violent crime. The impact of these findings on policy is less apparent. Though these findings may be statistically significant, the effects sizes are so small as to provide no reason to believe substantial policy changes would impact conceal carry application rates. Ostensibly, less guns on the street is a good thing, however even an extreme reduction in violent crime would only have a minimal effect on the number of concealed carry applications and permits issued.

The present study is not without limitations. Fear of crime has been shown to influence civilian gun ownership (Miethe, 1995; Warr \& Ellison, 2000), and we extend that argument to include concealed carry applications permits. However, we do not directly measure "fear of crime.” We infer that actual crime (in our case armed violent crime) motivates civilians to apply for concealed carry permits. In an optimal world we measure fear of crime more directly, perhaps though surveys. However, that would bring with it a number of other complications. First, with a small fraction of the population actually applying for these licenses, it would be very difficult to include enough applicants in a random sample of Floridians. Additionally, concealed carry 
applicants and permit holders are exempt from public record requests in Florida, which prevents a direct sampling of applicants and permit holders.

Another limitation, as mentioned previously, the appropriate unit of analysis in macro/meso-level research has been a point of contention among scholars. The less-than pristine approach of using UCR county-level crime data, for the potentially problematic reasons discussed by Maltz and Targonski (2002) and Pridemore (2005), was determined to be the most appropriate method available. The aforementioned justification for examining county-level effects of armed violent crime on concealed carry applications and permits is coupled with the availability of such data. Due to legislation safeguarding concealed carry permit-holder information; county-level data are perhaps the most-fine grained source of administrative insight available in the state of Florida.

We acknowledge that the use of Florida as a state to conduct concealed carry-related research has been called into question. Though the present study is not directed toward the potential impacts of shall-issue laws, Black and Nagin (1998) contend that estimates of shall-issue law effects are extremely sensitive to the inclusion of Florida to the extent that models including Florida, or of Florida itself, produce systematic prediction errors while others have found Florida to negatively skew crime estimates related to concealed carry laws (Kovandzic \& Marvell, 2003). The present research utilized Florida given its availability of data as well as the state's culture surrounding firearm prevalence, violent crime rates, and that the state currently has the most active concealed carry permits per capita in the United States.

Moreover, Florida’s “stand-your-ground” law allows legal gun carriers to use firearms in self-defense when they believe they are in danger of death or serious bodily harm. Stand-yourground laws remove an individual's duty to retreat, even if a safe route of retreat or escape is available, from any place a person has a lawful right to be. The present research is not concerned 
with the plausible link between stand-your-ground laws and violent crime, but such laws do possibly create a sense of legislative empowerment for individuals to seek protective mechanisms in the form of a concealed firearm. Citizens living in states that legally require people to retreat, as opposed to stand-your-ground, may feel a concealed carry weapon will be less effective in the face of a violent offender given a more stringent legal threshold for the justification of using the firearm for self-protection. Floridians may perceive the state's stand-your-ground laws as a mechanism to enhance the effectiveness of a concealed firearm as a legitimate means of selfprotective behavior.

In conclusion, the present study has demonstrated a significant relationship between firearm crime and subsequent applications and issuance of concealed carry gun permits. This finding was consistent across two temporal periods and net other informative covariates. Scholars should seek to build upon these findings to further explore the nexus between the levels of violence in crime incidents, individual fear of crime, and a desire pursue self-protection in the form of concealed gun carrying. 


\section{References}

Ayers, I. \& Donohue III, J. J. (1999). Nondiscretionary concealed weapons law: A case study of statistics, standards of proof, and public policy. American Law and Economics Review, 1, 436-470.

Bankston, W. B. \& Thompson, C. Y. (1989). Carrying firearms for protection: A causal model. Sociological Inquiry, 59, 75-87.

Bankston, W. B., Thompson, C. Y., Jenkins, Q, \& Forsyth, C. J. (1990). The influence of fear of crime, gender, and southern culture on carrying firearms for protection. The Sociological Quarterly, 31, 287-305.

Becker, G. S. (1976). The Economic Approach to Human Behavior. Chicago: University of Chicago Press.

Bellair, P. E. (1997). Social interaction and community crime: Examining the importance of neighbor networks. Criminology, 35, 677-704.

Black, D. (1980). The Manners and Customs of the Police. New York: Academic Press.

Black, D. D. \& Nagin, D. S. (1998). Do ‘right to carry’ laws reduce violent crime? Journal of Legal Studies, 27, 209-219.

Bordua, D. J. \& Lizotte, A. J. (1979). Patterns of legal firearms ownership: A cultural and situational analysis of Illinois counties. Law and Policy Quarterly, 1, 147-174.

Box, S., Hale, C. \& Andrews, G. (1988). Explaining fear of crime. British Journal of Criminology, 28, 340-356.

Brantingham, P. J. \& Brantingham, P. L. (1991). Environmental Criminology. Prospect Heights, IL: Waveland Press.

Browning, C. R., Dietz, R. D. \& Feinburg, S. L. (2004). The paradox of social organization: Networks, collective efficacy, and violent crime in urban neighborhoods. Social Forces, 83, 503-534.

Cameron, A. C. \& Trivedi. P. K. (2013). Regression Analysis of Count Data. Cambridge, UK: Cambridge University Press.

Cao, L., Cullen, F. T., \& Link, B. G. (1997). The social determinants of gun ownership: Selfprotection in an urban environment. Criminology, 35(4), 629-658.

Carlson, J. D. (2012). 'I don’t dial 911': American gun politics and the problem of policing. British Journal of Criminology, 52(6), 1113-1132.

Cohen, J. \& Tita, G. (1999). Diffusion in homicide: Exploring a general method for detecting spatial diffusion processes. Journal of Quantitative Criminology, 15, 451-493.

Cook, P. J. (1991). The technology of personal violence. In M. Tonry, (Ed.), Crime and Justice: A Review of Research (pp. 1-71). Chicago: University of Chicago Press.

Cornish, D. B. \& Clarke, R. V. (1987). Understanding crime displacement: an application of rational choice theory. Criminology, 25(4), 933-947.

Costanza, S. E. \& Kilburn, Jr., J. C. (2004). Circling the welcome wagons: Area, income, race, and legal hand-gun concealment. Criminal Justice Review, 29, 289-303.

Costanza, S. E., Kilburn, Jr., J. C., \& Miles, B. (2013). The spatial dynamics of handgun concealment. Crime Mapping, 5(1), 39-62.

Dixon, J. \& Lizotte, A. J. (1987). Gun ownership and the "southern subculture of violence.” American Journal of Sociology, 93, 383-405. 
Donohue, J. J. \& Ayers, I. (1999). Nondiscretionary concealed weapons law: A case study of statistics, standards of proof, and public policy. American Law and Economics Review, 1, 436-463.

Drakulich, K. M. (2015). Social capital, information, and perceived safety from crime: The differential effects of reassuring social connections and vicarious victimization. Social Science Quarterly, 96(1), 176-190.

Driscoll, J. C. \& Kraay, A. C. (1998). Consistent covariance matrix estimation with spatially dependent panel data. Review of Economics and Statistics, 80, 549-560.

Felson, R. B. \& Pare, P. (2010). Gun cultures or honor cultures? Explaining regional and race differences in weapon carrying. Social Forces, 88, 1357-1378.

Florida Department of Agriculture and Consumer Services. (2015). Number of Licenses by Type. Florida Division of Licensing. Retrieved from http://www.freshfromflorida.com/content/download/7471/118627/Number_of_Licensees _By_Type.pdf

Gardner, W., Mulvey, E. P. \& Shaw, E. C. (1995). Regression analyses of counts and rates: Poisson, overdispersed poisson, and negative binomial models. Psychological Bulletin, 118, 392-404.

Gau, J. M. (2008). A neighborhood-level analysis of concealed hand-gun permits. Policing: An International Journal of Police Strategies and Management, 31, 674-693.

Garland, D. (2002). The Culture of Control: Crime and Social Order in Contemporary Society. Chicago: University of Chicago Press.

Giblin, M. J., Burruss, G. W., Corsaro, N. \& Schafer, J. A. (2012). Self-protection in rural America: A risk interpretation model of household protective measures. Criminal Justice Policy Review, 23, 493-517.

Grossman, R. S. \& Lee, S. A. (2008). May issue versus shall issue: Explaining the pattern of concealed-carry handgun laws, 1960-2001. Contemporary Economic Policy, 26, 198-206.

Hartman, R. S. (1982). A note on the use of aggregate data in individual choice models: Discrete consumer choice among alternative fuels for residential appliances. Journal of Econometrics, 18(3), 313-335.

Hausman, J. A. (1978). Specification tests in econometrics. Econometrica, 46(6), 1251-1271.

Hood III, M. V. \& Neeley, G. W. (2000). Citizen, defend thyself: An individual-level analysis of concealed weapon permit holders. Criminal Justice Studies, 22, 73-89.

Kleck, G. \& DeLone, M. A. (1993). Victim resistance and offender weapon effects in robbery. Journal of Quantitative Criminology, 9, 55-81.

Kleck, G. \& Kovandzic, T. V. (2009). City-level characteristics and individual handgun ownership: Effects of collective security and homicide. Journal of Contemporary Criminal Justice, 25, 45-66.

Kovandzic, T. V. \& Marvell, T. B. (2003). Right-to-carry concealed handguns and violent crime: Crime control through gun decontrol? Criminology and Public Policy, 2, 363-396.

Kovandzic, T. V. \& Sloan, J. J. (2002). Police levels and crime rates revisited: A county-level analysis from Florida (1980-1998). Journal of Criminal Justice, 30, 65-76.

Land, K. C., McCall, P. L. \& Cohen, L. E. (1990). Structural covariates of homicide rates: Are there any invariances across time and social space? American Journal of Sociology, 95, 922-963. 
Lauritsen, J. L. \& Carbone-Lopez, K. (2011). Gender differences in risk factors for violent victimization: An examination of individual-, family-, and community-level predictors. Journal of Research in Crime and Delinquency, 48, 538-565.

Levitt, S. D. (1998). Juvenile crime and punishment. Journal of Political Economy, 106(61), 1156-1185.

Lindegaard, M. R., Bernasco, W. \& Jacques, S. (2014). Consequences of expected and observed victim resistance for offender violence during robbery events. Journal of Research in Crime and Delinquency. doi:10.1177/0022427814547639.

Lizotte, A. J., Bordua, D. J. \& White, C. S. (1981). Firearms ownership for sport and protection: Two not so divergent models: Correction. American Sociological Review, 46, 499-503.

Lott, Jr., J. R. (2000). More Guns, Less Crime: Understanding Crime and Gun Control Laws. Chicago: The University of Chicago Press.

Lott, Jr., J. R. \& Mustard, D. (1997). Crime, deterrence and right-to-carry concealed handguns. Journal of Legal Studies, 26, 1-68.

Lott, Jr., J. R. \& Whitley, J. (2003). Measurement error in county-level data. Journal of Quantitative Criminology, 19, 185-198.

Ludwig, J. (2000). Gun self-defense and deterrence. Crime and Justice, 27, 363-417.

Maltz, M. D. \& Targonski, J. (2002). A note on the use of county-level UCR data. Journal of Quantitative Criminology, 18, 297-318.

Marvell, T. B. \& Moody, C. E. (1996). Specification problems, police levels, and crime rates. Criminology, 34, 609-646.

McCall, P. L., Land, K. C. \& Parker, K. F. (2010). An empirical assessment of what we know about structural covariates of homicide rates: A return to a classic 20 years later. Homicide Studies, 14, 219-243.

McDowall, D. \& Loftin, C. (1983). Collective security and the demand for legal handguns. American Journal of Sociology, 88, 1146-1161.

Mears, D. P. \& Bhati, A. S. (2006). No community is an island: The effects of resource deprivation on urban violence in spatially and socially proximate communities. Criminology, 44, 409-548.

Miethe, T. D. (1995). Fear and withdrawal from urban life. The ANNALS of the American Academy of Political and Social Science, 539, 14-27.

Moody, C. E. (2001). Testing for the effects of concealed weapons laws: Specification errors and robustness. Journal of Law and Economics, 44, 799-813.

Morenoff, J. D. \& Sampson, R. J. (1997). Violent crime and the spatial dynamics of neighborhood transition: Chicago, 1970-1990. Social Forces, 76. 31-64.

Morenoff, J. D., Sampson, R. J. \& Raudenbush, S. W. (2001). Neighborhood inequality, collective efficacy, and spatial dynamics of urban violence. Criminology, 39, 517-560.

National Research Council. (2004). Firearms and Violence: A Critical Review. Washington: The National Academies Press.

Osgood, D. W. (2000). Poisson-based regression analysis of aggregate crime rates. Journal of Quantitative Criminology, 16, 21-43.

Osgood, D. W. \& Chambers, J. M. (2000). Social disorganization outside the metropolis: An analysis of rural youth violence. Criminology, 38, 81-116.

Plassmann, F. \& Tideman, T. N. (2001). Does the right to carry concealed handguns deter countable crimes? Only a count analysis can say. Journal of Law and Economics, 44(2), 771-798. 
Pridemore, W. A. (2005). A cautionary note on using county-level crime and homicide data. Homicide Studies, 9, 256-268.

Sampson, R. J., Raudenbushm, S. W. \& Earls, F. (1997). Neighborhoods and violent crime: A multilevel study of collective efficacy. Science, 277, 918-924.

Simon, J. (2002). Guns, crime, and governance: A comment on Robert Weisberg's Frankel Lecture. Houston Law Review, 39, 133-148.

Simon, J. (2004). Gun rights and the constitutional significance of violent crime. William and Mary Bill of Rights Journal, 12, 335-356.

Simon, J. (2007). Governing through Crime: How the War on Crime Transformed American Democracy and Created a Culture of Fear. New York: Oxford University Press.

Smith, W. R., Frazee, F. G. \& Davison, E. L. (2000). Furthering the integration of routine activity and social disorganization theories: Small units of analysis and the study of street robbery as a diffusion process. Criminology, 38, 489-523.

Smith, D. A. \& Uchida, C. D. (1988). The social organization of self-help: A study of defensive weapon ownership. American Sociological Review, 53(1), 94-102.

Stolzenberg, L. \& D’Alessio, S. J. (2000). Gun availability and violent crime. Social Forces, 78, 1461-1482.

Tabachnick, B. \& Fidell, L. (2001). Using Multivariate Statistics. New York: Pearson.

Thompson, J. A. \& Stidham, R. (2010). Packing heat in the tar heel state: A county-level assessment of concealed carry permits. Criminal Justice Review, 35, 52-66.

Truman, J., Langton, L. \& Planty, M. (2013). Criminal Victimization, 2012. Washington: Bureau of Justice Statistics.

Tyler, T. R. (1980). Impact of directly and indirectly experienced events: The origins of crimerelated judgments and behaviors. Journal of Personality and Social Psychology, 39, 1328.

Vacha, E. F. \& McLaughlin, T. F. (2000). The impact of poverty, fear of crime, and crime victimization on keeping firearms for protection and unsafe gun storage practices: A review and analysis with policy recommendations. Urban Education, 35, 496-510.

Warr, M. (1987). Fear of victimization and sensitivity to risk. Journal of Quantitative Criminology, 3, 29-46.

Warr, M. \& Ellison, C. G. (2000). Rethinking social reactions to crime: Personal and altruistic fear in family households. American Journal of Sociology, 106, 551-578.

Watkins, A. M., Huebner, B. M. \& Decker, S. H. (2008). Patterns of gun acquisition, carrying, and use among juvenile and adult arrestees: Evidence from a high-crime city. Justice Quarterly, 25, 674-700.

Wilcox-Rountree, P. (1998). A reexamination of the crime-fear linkage. Journal of Research in Crime and Delinquency, 35, 341-372.

Wright, J. D. \& Rossi, P. H. (1994). Armed and Considered Dangerous. A Survey of Felons and Their Firearms, expanded ed. New York: Aldine de Gruyter.

Young, R. L., McDowall, D. \& Loftin, C. (1987). Collective security and the ownership of firearms for protection. Criminology, 25, 47-62.

Zimring, F. E. \& Hawkins, G. (1997). Concealed handguns: The counterfeit deterrent. Responsive Community, 7, 46-60. 


\section{Tables}

Table 1. Florida County Level Descriptive Statistics for Dependent and Independent Variables for 2005-2012 and 1997-2012

\begin{tabular}{|c|c|c|c|c|c|c|c|c|}
\hline & \multicolumn{4}{|c|}{$2005-2012$} & \multicolumn{4}{|c|}{$1997-2012$} \\
\hline $\mathrm{N}=536$ & Mean & $\begin{array}{c}\text { Standard } \\
\text { Deviation }\end{array}$ & Minimum & Maximum & Mean & $\begin{array}{c}\text { Standard } \\
\text { Deviation }\end{array}$ & Minimum & Maximum \\
\hline Concealed Carry Applications & 1380.49 & 2116.36 & 6 & 13123 & 831.48 & 1583.38 & 1 & 13123 \\
\hline $\begin{array}{l}\text { Concealed Carry Applications } \\
\text { per } 100 \mathrm{k}\end{array}$ & 521.44 & 281.77 & 75.27 & 1874.11 & 325.28 & 271.86 & 14.02 & 1874.11 \\
\hline $\begin{array}{l}\text { Concealed Carry Permits } \\
\text { Concealed Carry Permits per }\end{array}$ & 536 & 7963.54 & 48 & 87998 & 5664.58 & 9981.7 & 19 & 87998 \\
\hline $\begin{array}{l}\text { 100k } \\
\text { Violent Crime w/ a Firearm per }\end{array}$ & 2878.75 & 1439.33 & 633.16 & 9406.06 & 2050.31 & 1325.63 & 181.07 & 9406.06 \\
\hline $\begin{array}{l}\text { 100k }{ }^{1,2} \\
\text { Violent Crime w/o Firearm per }\end{array}$ & 99.34 & 68.98 & 0 & 482.18 & 108.91 & 74.05 & 0 & 566.53 \\
\hline $100 \mathrm{k}$ & 412.36 & 199.52 & 35.84 & 1385.68 & 470.74 & 223.41 & 35.84 & 1385.68 \\
\hline Unemployment Rate & 7.08 & 3.26 & 2.10 & 15.60 & 5.96 & 2.81 & 2.1 & 15.6 \\
\hline Income Per Capita ${ }^{3}$ & 32.54 & 10.02 & 15.47 & 66.43 & 27.936 & 9.73 & 11.21 & 66.43 \\
\hline Percent White & 70.78 & 14.29 & 15.40 & 91.20 & 74.58 & 14.29 & 15.4 & 97.1 \\
\hline Percent Republican & 35.02 & 11.33 & 7.90 & 63.30 & 33.6 & 13.41 & 3.66 & 63.7 \\
\hline Population Per Square Mile & 336.58 & 524.05 & 9.07 & 3462.75 & 311.37 & 505.25 & 8.40 & 3462.75 \\
\hline Sworn Officers per 100k & 222.56 & 117.73 & 57.24 & 1115.84 & 218.94 & 98.16 & 51.81 & 1115.84 \\
\hline Hunting Licenses per 100k & 1197.39 & 1290 & 39.70 & 6115.23 & & & & \\
\hline
\end{tabular}

${ }^{1}$ Violent crime consists of data from the UCR: homicide, rape, robbery and aggravated assault and is incidents per 100,000 of population.

${ }^{2}$ The remaining "0" in the "Violent Crime w a Firearm" variable from three counties in four years. Each county is sparsely populated and sees very little violent crime, and even less violent crime with firearms. Additionally, the authors discussed the " 0 " values with FDLE Crime Statistics Personnel and were assured those particular values were actually reported as “0” and not "missing”.

${ }^{3}$ Income per capita is in thousands of dollars.

${ }^{4}$ Overall standard deviations are reported as opposed to within-county standard deviations. The latter is arguably more appropriate given the unit of analysis. However, overall standard deviations are believed to best describe the data and illustrate variance across the state of Florida as within-county standard deviations would be highly suppressed in cases where within-county measures (such as racial or political composition) are not likely to vary from year to year. 
Table 2. Unstandardized Negative Binomial Regression Coefficients from Multiple Regression of Concealed Carry Applications on Violent Crime and Control Variables with County and Year Fixed Effects. ${ }^{1}$

\begin{tabular}{|c|c|c|c|c|c|c|c|c|}
\hline \multirow[b]{2}{*}{ Violent Crime w/ Firearm } & \multicolumn{2}{|c|}{$\begin{array}{c}\text { All Counties } \\
\text { Concealed Carry } \\
\text { Applications } \\
2005 \text { - } 2012\end{array}$} & \multicolumn{2}{|c|}{$\begin{array}{c}\text { Limited Counties } \\
\text { Concealed Carry } \\
\text { Applications } \\
2005-2012^{2}\end{array}$} & \multicolumn{2}{|c|}{$\begin{array}{c}\text { All Counties } \\
\text { Concealed Carry } \\
\text { Applications } \\
1997 \text { - } 2012\end{array}$} & \multicolumn{2}{|c|}{$\begin{array}{c}\text { Limited Counties } \\
\text { Concealed Carry } \\
\text { Applications } \\
1997-2012^{2}\end{array}$} \\
\hline & $0.0006 * *$ & $(0.0002)$ & $0.0007 * * *$ & $(0.0002)$ & $0.0009 * * *$ & $(0.0002)$ & $0.0010 * * *$ & $(0.0002)$ \\
\hline Violent Crime w/o Firearm & 0.0001 & $(0.0001)$ & -0.0001 & $(0.0001)$ & $-0.0002^{* *}$ & $(0.0001)$ & $-0.0002 * * *$ & $(0.0001)$ \\
\hline Unemployment & $-0.0418 * * *$ & $(0.0101)$ & $-0.0369 * * *$ & $(0.0108)$ & $-0.0408 * * *$ & $(0.0071)$ & $-0.0378 * * *$ & $(0.0076)$ \\
\hline Per Capita Income & 0.0029 & $(0.0040)$ & 0.0071 & $(0.0041)$ & -0.0014 & $(0.0025)$ & 0.0014 & $(0.0026)$ \\
\hline Percent White & $0.0081 * *$ & $(0.0026)$ & $0.0080 * *$ & $(0.0028)$ & 0.0002 & $(0.0012)$ & -0.0001 & $(0.0012)$ \\
\hline Percent Republican & 0.0010 & $(0.0024)$ & 0.0035 & $(0.0025)$ & -0.0015 & $(0.0017)$ & 0.0019 & $(0.0018)$ \\
\hline Population Per Square Mile & $-0.0009 * * *$ & $(0.0002)$ & $-0.0007 * * *$ & $(0.0002)$ & $-0.0008 * * *$ & $(0.0001)$ & $-0.0006 * * *$ & $(0.0001)$ \\
\hline Sworn Officers Per 100k & 0.0003 & $(0.0002)$ & 0.0002 & $(0.0002)$ & $0.0005 * * *$ & $(0.0001)$ & $0.0005 * * *$ & $(0.0002)$ \\
\hline Hunting Licenses Per 100k & $0.0002 * * *$ & $(0.0000)$ & $0.0002 * * *$ & $(0.0001)$ & & & & \\
\hline Groups & 67 & & 55 & & 67 & & 55 & \\
\hline Observations Per Group & 8 & & 8 & & 16 & & 16 & \\
\hline $\mathrm{N}$ & 536 & & 440 & & 1072 & & 880 & \\
\hline Wald Chi ${ }^{2}$ & 5344.85 & & 4951.53 & & 18472.90 & & 17591.57 & \\
\hline
\end{tabular}

'Standard errors are presented next to the coefficients in each model. The Negative Binomial models were estimated with county and year fixed effects, those results are omitted.

${ }^{2}$ The following counties are removed from the analysis: Calhoun, Franklin, Gilchrist, Glades, Gulf, Hamilton, Holmes, Jefferson, Lafayette, Liberty, Okeechobee and Suwannee.

$* p<.05,{ }^{* *} p<.01, * * * p<.001$ in a two-tailed test. 
Table 3. Unstandardized Negative Binomial Regression Coefficients from Multiple Regression of Concealed Carry Permits on Violent Crime and Control Variables with County and Year Fixed Effects. ${ }^{1}$

\begin{tabular}{|c|c|c|c|c|c|c|c|c|}
\hline \multirow[b]{2}{*}{ Violent Crime w/ Firearm } & \multicolumn{2}{|c|}{$\begin{array}{c}\text { All Counties } \\
\text { Concealed Carry Permits } \\
2005-2012 \\
\end{array}$} & \multicolumn{2}{|c|}{$\begin{array}{c}\text { Limited Counties } \\
\text { Concealed Carry Permits } \\
2005-2012^{2}\end{array}$} & \multicolumn{2}{|c|}{$\begin{array}{c}\text { All Counties } \\
\text { Concealed Carry Permits } \\
1997-2012 \\
\end{array}$} & \multicolumn{2}{|c|}{$\begin{array}{c}\text { Limited Counties } \\
\text { Concealed Carry Permits } \\
1997-2012^{2} \\
\end{array}$} \\
\hline & $0.0004^{* * *}$ & $(0.0001)$ & $0.0004 * *$ & $(0.0001)$ & $0.0008 * * *$ & $(0.0001)$ & $0.0008 * * *$ & $(0.0001)$ \\
\hline Violent Crime w/o Firearm & 0.0001 & $(0.0001)$ & 0.0001 & $(0.0001)$ & $0.0001 * *$ & $(0.0000)$ & $0.0001^{* *}$ & $(0.0000)$ \\
\hline Unemployment & $-0.0353 * * *$ & $(0.0063)$ & $-0.0313 * * *$ & $(0.0067)$ & -0.0081 & $(0.0049)$ & -0.0033 & $(0.0053)$ \\
\hline Per Capita Income & 0.0012 & $(0.0028)$ & 0.0028 & $(0.00029)$ & $-0.0150 * * *$ & $(0.0022)$ & $-0.0124 * * *$ & $(0.0023)$ \\
\hline Percent White & $0.0057^{* * *}$ & $(0.0018)$ & 0.0051 & $(0.0019)$ & $0.0035 * * *$ & $(0.0008)$ & $0.0034 * * *$ & $(0.0009)$ \\
\hline Percent Republican & 0.0022 & $(0.0015)$ & 0.0029 & $(0.0016)$ & 0.0022 & $(0.0012)$ & $0.0048 * * *$ & $(0.0013)$ \\
\hline Population Per Square Mile & $-0.0005 * * *$ & $(0.0001)$ & $-0.0004^{* * *}$ & $(0.0001)$ & $-0.0009 * * *$ & $(0.0001)$ & $-0.0006 * * *$ & $(0.0001)$ \\
\hline Sworn Officers Per 100k & 0.0002 & $(0.0001)$ & 0.0002 & $(0.0001)$ & $0.0005 * * *$ & $(0.0001)$ & $0.0007 * * *$ & $(0.0001)$ \\
\hline Hunting Licenses Per 100k & -0.0001 & $(0.0000)$ & -0.0001 & $(0.0001)$ & & & & \\
\hline Groups & 67 & & 55 & & 67 & & 55 & \\
\hline Observations Per Group & 8 & & 8 & & 16 & & 16 & \\
\hline $\mathrm{N}$ & 536 & & 440 & & 1072 & & 880 & \\
\hline Wald $\mathrm{Chi}^{2}$ & 12641.34 & & 11798.19 & & 16996.97 & & 14940.21 & \\
\hline
\end{tabular}

${ }^{1}$ Standard errors are presented next to the coefficients in each model. The Negative Binomial models were estimated with county and year fixed effects, those results are omitted.

${ }^{2}$ The following counties are removed from the analysis: Calhoun, Franklin, Gilchrist, Glades, Gulf, Hamilton, Holmes, Jefferson, Lafayette, Liberty, Okeechobee and Suwannee.

$* p<.05,{ }^{* *} p<.01, * * * p<.001$ in a two-tailed test. 
Table 4. Unstandardized Negative Binomial Regression Coefficients from Multiple Regression of Concealed Carry Applications on Violent Crime Types and Control Variables with County and Year Fixed Effects. ${ }^{1}$

\begin{tabular}{|c|c|c|c|c|c|c|c|c|}
\hline & \multicolumn{4}{|c|}{ Concealed Carry Applications 2005 - 2012} & \multicolumn{4}{|c|}{ Concealed Carry Applications 1997 - 2012} \\
\hline Firearm Homicide & $\begin{array}{c}0.0025 \\
(0.0037)\end{array}$ & & & & $\begin{array}{c}0.0130 * * * \\
(0.0033)\end{array}$ & & & \\
\hline Firearm Rape & & $\begin{array}{c}0.0079 \\
(0.0068)\end{array}$ & & & & $\begin{array}{c}-0.0087 \\
0.0050\end{array}$ & & \\
\hline Firearm Robbery & & & $\begin{array}{c}0.0009 * * \\
0.0004\end{array}$ & & & & $\begin{array}{c}0.0008 * * \\
(0.0003)\end{array}$ & \\
\hline Firearm Aggravated Assault & & & & $\begin{array}{c}0.0010 * * \\
(0.0004)\end{array}$ & & & & $\begin{array}{c}0.0013 * * * \\
(0.0003)\end{array}$ \\
\hline Unemployment & $\begin{array}{c}-0.0476 * * * \\
(0.0100)\end{array}$ & $\begin{array}{c}-0.0478 * * * \\
(0.0100)\end{array}$ & $\begin{array}{c}-0.0432 * * * \\
(0.0101)\end{array}$ & $\begin{array}{c}-0.0448 * * * \\
(0.0100)\end{array}$ & $\begin{array}{c}-0.0393 * * * \\
(0.0072)\end{array}$ & $\begin{array}{c}-0.0414 * * * \\
(0.0058)\end{array}$ & $\begin{array}{c}-0.0394 * * * \\
(0.0073)\end{array}$ & $\begin{array}{c}-0.0429 * * * \\
(0.0072)\end{array}$ \\
\hline Per Capita Income & $\begin{array}{c}0.0018 \\
(0.0040)\end{array}$ & $\begin{array}{c}0.0002 \\
(0.0019)\end{array}$ & $\begin{array}{c}0.0023 \\
(0.0040)\end{array}$ & $\begin{array}{c}0.0024 \\
(0.0040)\end{array}$ & $\begin{array}{c}-0.0014 \\
(0.0024)\end{array}$ & $\begin{array}{l}-0.0019 \\
(0.0024)\end{array}$ & $\begin{array}{l}-0.0019 \\
(0.0025)\end{array}$ & $\begin{array}{l}-0.0017 \\
(0.0025)\end{array}$ \\
\hline Percent White & $\begin{array}{c}0.0083^{* *} \\
(0.0026)\end{array}$ & $\begin{array}{c}0.0039 \\
(0.0026)\end{array}$ & $\begin{array}{l}0.0079 * * \\
(0.0026)\end{array}$ & $\begin{array}{c}0.0082 * * * \\
(0.0026)\end{array}$ & $\begin{array}{c}0.0009 \\
(0.0012)\end{array}$ & $\begin{array}{r}0.0018 \\
(0.0013)\end{array}$ & $\begin{array}{c}0.0006 \\
(0.0013)\end{array}$ & $\begin{array}{c}0.0003 \\
(0.0012)\end{array}$ \\
\hline Percent Republican & $\begin{array}{c}0.0018 \\
(0.0023)\end{array}$ & $\begin{array}{c}0.0018 \\
(0.0023)\end{array}$ & $\begin{array}{c}0.0016 \\
(0.0023)\end{array}$ & $\begin{array}{c}0.0019 \\
(0.0023)\end{array}$ & $\begin{array}{l}-0.0016 \\
(0.0017)\end{array}$ & $\begin{array}{r}-0.0023 \\
(0.0017)\end{array}$ & $\begin{array}{l}-0.0023 \\
(0.0017)\end{array}$ & $\begin{array}{l}-0.0019 \\
(0.0017)\end{array}$ \\
\hline Population Per Square Mile & $\begin{array}{c}-0.0009 * * * \\
(0.0002)\end{array}$ & $\begin{array}{c}-0.0009 * * * \\
(0.0002)\end{array}$ & $\begin{array}{c}-0.0009 * * * \\
(0.0002)\end{array}$ & $\begin{array}{c}-0.0009 * * * \\
(0.0002)\end{array}$ & $\begin{array}{c}-0.0009 * * * \\
(0.0001)\end{array}$ & $\begin{array}{c}-0.0009 * * * \\
(0.0001)\end{array}$ & $\begin{array}{c}-0.0009 * * * \\
(0.0001)\end{array}$ & $\begin{array}{c}-0.0009 * * * \\
(0.0001)\end{array}$ \\
\hline Sworn Officers Per 100k & $\begin{array}{c}0.0003 \\
(0.0002)\end{array}$ & $\begin{array}{c}0.0003 \\
(0.0002)\end{array}$ & $\begin{array}{c}0.0003 \\
(0.0002)\end{array}$ & $\begin{array}{c}0.0003 \\
(0.0002)\end{array}$ & $\begin{array}{c}0.0005 * * * \\
(0.0001)\end{array}$ & $\begin{array}{l}0.0005 * * * \\
(0.0001)\end{array}$ & $\begin{array}{c}0.0005 * * * \\
(0.0001)\end{array}$ & $\begin{array}{l}0.0004 * * \\
(0.0001)\end{array}$ \\
\hline Hunting Licenses Per 100k & $\begin{array}{c}0.0002 * * * \\
(0.0000)\end{array}$ & $\begin{array}{c}0.0002^{* * *} \\
(0.0000)\end{array}$ & $\begin{array}{c}0.0002 * * * \\
(0.0000)\end{array}$ & $\begin{array}{c}0.0002^{* * *} \\
(0.0000)\end{array}$ & & & & \\
\hline Groups & 67 & 67 & 67 & 67 & 67 & 67 & 67 & 67 \\
\hline Observations Per Group & 8 & 8 & 8 & 8 & 16 & 16 & 16 & 16 \\
\hline $\mathrm{N}$ & 536 & 536 & 536 & 536 & 1072 & 1072 & 1072 & 1072 \\
\hline Wald $\mathrm{Chi}^{2}$ & 5115.01 & 5141.53 & 5269.86 & 5267.64 & 17724.65 & 17058.73 & 17810.13 & 17897.51 \\
\hline
\end{tabular}

${ }^{1}$ Models include all Florida counties. Standard errors are presented in parentheses below the coefficients is each model. The Negative Binomial models were estimated with county and year fixed effects, those results are omitted.

Note: All 67 counties are included in each model in Table 4.

$* p<.05, * * p<.01, * * * p<.001$ in a two-tailed test. 
Table 5. Unstandardized Negative Binomial Regression Coefficients from Multiple Regression of Concealed Carry Permits on Violent Crime Types and Control Variables with County and Year Fixed Effects. ${ }^{1}$

\begin{tabular}{|c|c|c|c|c|c|c|c|c|}
\hline & \multicolumn{4}{|c|}{ Concealed Carry Permits 2005 - 2012} & \multicolumn{4}{|c|}{ Concealed Carry Permits $1997-2012$} \\
\hline Firearm Homicide & $\begin{array}{l}0.0061^{*} \\
(0.0026)\end{array}$ & & & & $\begin{array}{c}0.0124 * * * \\
(0.0024)\end{array}$ & & & \\
\hline Firearm Rape & & $\begin{array}{c}0.0151^{* * *} \\
(0.0047)\end{array}$ & & & & $\begin{array}{c}0.0125 * * * \\
(0.0038)\end{array}$ & & \\
\hline Firearm Robbery & & & $\begin{array}{c}0.0007 * * * \\
(0.0002)\end{array}$ & & & & $\begin{array}{c}0.0013 * * * \\
(0.0002)\end{array}$ & \\
\hline Firearm Aggravated Assault & & & & $\begin{array}{c}0.0007^{* *} \\
(0.0002)\end{array}$ & & & & $\begin{array}{c}0.0014^{* * *} \\
(0.0002)\end{array}$ \\
\hline Unemployment & $\begin{array}{c}-0.0376 * * * \\
(0.0063)\end{array}$ & $\begin{array}{c}-0.0377 * * * \\
(0.0062)\end{array}$ & $\begin{array}{c}-0.0356 * * * \\
(0.0063)\end{array}$ & $\begin{array}{c}-0.0374 * * * \\
(0.0063)\end{array}$ & $\begin{array}{l}-0.0088 \\
(0.0051)\end{array}$ & $\begin{array}{c}-0.0101 \\
(0.0051)\end{array}$ & $\begin{array}{l}-0.0076 \\
(0.0050)\end{array}$ & $\begin{array}{l}-0.0119 * \\
(0.0050)\end{array}$ \\
\hline Per Capita Income & $\begin{array}{c}0.0012 \\
(0.0028)\end{array}$ & $\begin{array}{c}0.0011 \\
(0.0028)\end{array}$ & $\begin{array}{c}0.0011 \\
(0.0028)\end{array}$ & $\begin{array}{c}0.0009 \\
(0.0028)\end{array}$ & $\begin{array}{c}-0.0133 * * * \\
(0.0022)\end{array}$ & $\begin{array}{c}-0.0129 * * * \\
(0.0021)\end{array}$ & $\begin{array}{c}-0.0145 * * * \\
(0.0022)\end{array}$ & $\begin{array}{c}-0.0143 * * * \\
(0.0022)\end{array}$ \\
\hline Percent White & $\begin{array}{c}0.0061^{* * *} \\
(0.0018)\end{array}$ & $\begin{array}{c}0.0060 * * * \\
(0.0018)\end{array}$ & $\begin{array}{c}0.0054^{* * *} \\
(0.0018)\end{array}$ & $\begin{array}{c}0.0062 * * * \\
(0.0018)\end{array}$ & $\begin{array}{c}0.0053^{* * *} \\
(0.0009)\end{array}$ & $\begin{array}{c}0.0054^{* * *} \\
(0.0009)\end{array}$ & $\begin{array}{c}0.0041^{* * *} \\
(0.0009)\end{array}$ & $\begin{array}{c}0.0044^{* * * *} \\
(0.0008)\end{array}$ \\
\hline Percent Republican & $\begin{array}{c}0.0023 \\
(0.0015)\end{array}$ & $\begin{array}{c}0.0023 \\
(0.0015)\end{array}$ & $\begin{array}{c}0.0020 \\
(0.0015)\end{array}$ & $\begin{array}{c}0.0022 \\
(0.0015)\end{array}$ & $\begin{array}{c}0.0020 \\
(0.0012)\end{array}$ & $\begin{array}{c}0.0017 \\
(0.0012)\end{array}$ & $\begin{array}{c}0.0017 \\
(0.0012)\end{array}$ & $\begin{array}{c}0.0022 \\
(0.0012)\end{array}$ \\
\hline Population Per Square Mile & $\begin{array}{c}-0.0006^{* * *} \\
(0.0001)\end{array}$ & $\begin{array}{c}-0.0005 * * * \\
(0.0001)\end{array}$ & $\begin{array}{c}-0.0006 * * * \\
(0.0001)\end{array}$ & $\begin{array}{c}-0.0005^{* * *} * \\
(0.0001)\end{array}$ & $\begin{array}{c}-0.0010 * * * \\
(0.0001)\end{array}$ & $\begin{array}{c}-0.0010 * * * \\
(0.0001)\end{array}$ & $\begin{array}{c}-0.0010 * * * \\
(0.0001)\end{array}$ & $\begin{array}{c}-0.0009 * * * \\
(0.0001)\end{array}$ \\
\hline Sworn Officers Per 100k & $\begin{array}{l}0.0002 * \\
(0.0001)\end{array}$ & $\begin{array}{c}0.0002 \\
(0.0001)\end{array}$ & $\begin{array}{c}0.0002 \\
(0.0001)\end{array}$ & $\begin{array}{c}0.0002 \\
(0.0001)\end{array}$ & $\begin{array}{c}0.0006^{* * *} \\
(0.0001)\end{array}$ & $\begin{array}{c}0.0005 * * * \\
(0.0001)\end{array}$ & $\begin{array}{c}0.0006 * * * \\
(0.0001)\end{array}$ & $\begin{array}{c}0.0005 * * * \\
(0.0001)\end{array}$ \\
\hline Hunting Licenses Per 100k & $\begin{array}{l}-0.0001 \\
(0.0001)\end{array}$ & $\begin{array}{l}-0.0001 \\
(0.0001)\end{array}$ & $\begin{array}{l}-0.0001 \\
(0.0001)\end{array}$ & $\begin{array}{l}-0.0001 \\
(0.0001)\end{array}$ & & & & \\
\hline Groups & 67 & 67 & 67 & 67 & 67 & 67 & 67 & 67 \\
\hline Observations Per Group & 8 & 8 & 8 & 8 & 16 & 16 & 16 & 16 \\
\hline $\mathrm{N}$ & 536 & 536 & 536 & 536 & 1072 & 1072 & 1072 & 1072 \\
\hline Wald Chi ${ }^{2}$ & 12116 & 12487.11 & 12501.30 & 12294.83 & 15682.30 & 15514.75 & 16297.14 & 16320.65 \\
\hline
\end{tabular}

${ }^{1}$ Notes: Models include all Florida counties. Standard errors are presented in parentheses below the coefficients is each model. The Negative Binomial models

were estimated with county and year fixed effects, those results are omitted.

Note: All 67 counties are included in each model in Table 5.

$* p<.05, * * p<.01, * * * p<.001$ in a two-tailed test. 
Appendix A

Correlation Matrix for Variables from 2005 - 2012

\begin{tabular}{|c|c|c|c|c|c|c|c|c|c|c|c|}
\hline & $\begin{array}{l}\text { CCW } \\
\text { Applications }\end{array}$ & $\begin{array}{l}\text { CCW } \\
\text { Permits }\end{array}$ & $\begin{array}{l}\text { Violent } \\
\text { Crime } \\
\text { w/ } \\
\text { Firearm }\end{array}$ & $\begin{array}{l}\text { Violent } \\
\text { Crime } \\
\text { w/o } \\
\text { Firearm }\end{array}$ & Unemployment & $\begin{array}{l}\text { Per } \\
\text { Capita } \\
\text { Income }\end{array}$ & $\begin{array}{l}\text { Percent } \\
\text { White }\end{array}$ & $\begin{array}{l}\text { Percent } \\
\text { Republican }\end{array}$ & $\begin{array}{l}\text { Population } \\
\text { Per Square } \\
\text { Mile }\end{array}$ & $\begin{array}{l}\text { Sworn } \\
\text { Officers } \\
\text { Per 100k }\end{array}$ & $\begin{array}{l}\text { Hunting } \\
\text { Licenses } \\
\text { Per 100k }\end{array}$ \\
\hline $\begin{array}{l}\text { CCW } \\
\text { Applications }\end{array}$ & 1 & & & & & & & & & & \\
\hline CCW Permits & 0.951 & 1 & & & & & & & & & \\
\hline $\begin{array}{l}\text { Violent Crime } \\
\text { w/ Firearm }\end{array}$ & 0.463 & 0.424 & 1 & & & & & & & & \\
\hline $\begin{array}{l}\text { Violent Crime } \\
\text { w/o Firearm }\end{array}$ & 0.067 & 0.061 & 0.522 & 1 & & & & & & & \\
\hline Unemployment & 0.247 & 0.209 & -0.004 & -0.182 & 1 & & & & & & \\
\hline $\begin{array}{l}\text { Per Capita } \\
\text { Income }\end{array}$ & 0.357 & 0.361 & 0.084 & -0.014 & 0.061 & 1 & & & & & \\
\hline Percent White & -0.416 & -0.425 & -0.483 & -0.340 & -0.135 & 0.074 & 1 & & & & \\
\hline $\begin{array}{l}\text { Percent } \\
\text { Republican }\end{array}$ & 0.104 & 0.091 & -0.076 & -0.184 & 0.062 & 0.545 & 0.400 & 1 & & & \\
\hline $\begin{array}{l}\text { Population Per } \\
\text { Square Mile }\end{array}$ & 0.654 & 0.671 & 0.413 & 0.128 & 0.041 & 0.353 & -0.206 & 0.145 & 1 & & \\
\hline $\begin{array}{l}\text { Sworn Officers } \\
\text { Per } 100 \mathrm{k}\end{array}$ & -0.060 & -0.058 & -0.010 & 0.099 & 0.080 & -0.015 & 0.003 & -0.133 & -0.082 & 1 & \\
\hline $\begin{array}{l}\text { Hunting } \\
\text { Licenses Per } \\
\text { 100k }\end{array}$ & -0.410 & -0.415 & -0.222 & -0.003 & -0.107 & -0.439 & 0.247 & -0.409 & -0.406 & 0.184 & 1 \\
\hline
\end{tabular}


Correlation Matrix for Variables from 1996 - 2012

\begin{tabular}{|c|c|c|c|c|c|c|c|c|c|c|}
\hline & $\begin{array}{l}\text { CCW } \\
\text { Applications }\end{array}$ & $\begin{array}{l}\text { CCW } \\
\text { Permits }\end{array}$ & $\begin{array}{l}\text { Violent } \\
\text { Crime w/ } \\
\text { Firearm }\end{array}$ & $\begin{array}{l}\text { Violent } \\
\text { Crime w/o } \\
\text { Firearm }\end{array}$ & Unemployment & $\begin{array}{l}\text { Per } \\
\text { Capita } \\
\text { Income }\end{array}$ & $\begin{array}{l}\text { Percent } \\
\text { White }\end{array}$ & $\begin{array}{l}\text { Percent } \\
\text { Republican }\end{array}$ & $\begin{array}{l}\text { Population } \\
\text { Per Square } \\
\text { Mile }\end{array}$ & $\begin{array}{l}\text { Sworn } \\
\text { Officers } \\
\text { Per 100k }\end{array}$ \\
\hline $\begin{array}{l}\text { CCW } \\
\text { Applications }\end{array}$ & 1 & & & & & & & & & \\
\hline CCW Permits & 0.921 & 1 & & & & & & & & \\
\hline $\begin{array}{l}\text { Violent Crime w/ } \\
\text { Firearm }\end{array}$ & 0.305 & 0.366 & 1 & & & & & & & \\
\hline $\begin{array}{l}\text { Violent Crime } \\
\text { w/o Firearm }\end{array}$ & 0.010 & 0.091 & 0.649 & 1 & & & & & & \\
\hline Unemployment & 0.297 & 0.219 & -0.007 & -0.166 & 1 & & & & & \\
\hline $\begin{array}{l}\text { Per Capita } \\
\text { Income }\end{array}$ & 0.438 & 0.427 & -0.026 & -0.083 & 0.148 & 1 & & & & \\
\hline Percent White & -0.383 & -0.406 & -0.359 & -0.205 & -0.205 & -0.049 & 1 & & & \\
\hline $\begin{array}{l}\text { Percent } \\
\text { Republican }\end{array}$ & 0.159 & 0.173 & -0.027 & -0.043 & 0.013 & 0.575 & 0.309 & 1 & & \\
\hline $\begin{array}{l}\text { Population Per } \\
\text { Square Mile }\end{array}$ & 0.555 & 0.634 & 0.355 & 0.191 & -0.004 & 0.350 & -0.157 & 0.246 & 1 & \\
\hline $\begin{array}{l}\text { Sworn Officers } \\
\text { Per 100k }\end{array}$ & -0.030 & -0.016 & 0.032 & 0.140 & 0.093 & 0.075 & -0.050 & -0.052 & -0.045 & 1 \\
\hline
\end{tabular}

